\section{The lived experience of undergraduate student parents: roles compatibility challenge}

\author{
Camila Lucchini-Raies \\ Francisca Márquez-Doren ${ }^{2}$ \\ Luz María Herrera-López ${ }^{3}$ \\ Camila Valdés ${ }^{4}$ \\ Náyade Rodríguez ${ }^{5}$
}

The lived experience of undergraduate student parents: roles compatibility challenge

Objective. To reveal the meanings attributed by university students to their experience of becoming a mother/father during their studies. Methods. A phenomenological study was conducted with students at a private Chilean University. Sixteen students from different undergraduate careers (eight women and eight men) participated in in-depth interviews, which were recorded. A phenomenological analysis of the data that followed the Streubert method was carried out, ensuring rigor by the criteria established by Guba and Lincoln during the research process. The ethical aspects were addressed through the process of informed consent, confidentiality and methodological rigor. Results. The phenomenon of becoming a mother/father during the university studies was revealed through four central themes: Emotions in conflict; Internal mobilization to address the situation; Position oneself in a new role; and Need for support. The central contribution of the study is the revelation of the transformation process towards the
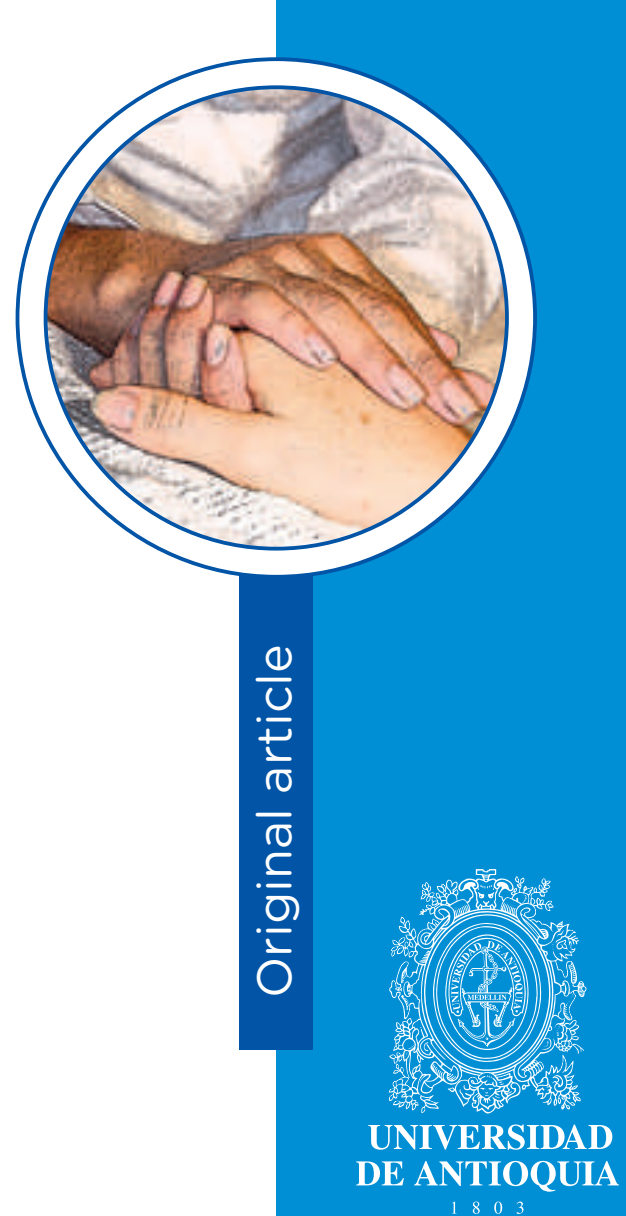

1 Nurse Midwife, MNSc. Ph.D.(c) Associate Professor, School of Nursing, Pontificia Universidad Católica de Chile.

email: clucchin@uc.cl

2 Nurse Midwife, MNSc, Ph.D. Associate Professor, School of Nursing, Pontificia Universidad Católica de Chile.

email: fmarquez@uc.cl. Corresponding Author.

3 Nurse Midwife. MNSc. Associate Professor, School of Nursing, Pontificia Universidad Católica de Chile. email: luzma@uc.cl

4 Nurse, Master Student. School of Nursing, Pontificia Universidad Católica de Chile. email: cavaldes@uc.cl

5 Nurse Midwife. Coordinator of the Healthy Campus Program. Department of Students Affairs. Pontificia Universidad Católica de Chile. email: nbrodrig@uc.cl

Conflicts of interest: None.

Funding: Research Direction of the School of Nursing at the Pontificia Universidad Católica de Chile (DIEE). No DIEE201204.

Received: February 21 ${ }^{\text {st }}, 2018$.

Accepted: May 31 ${ }^{\text {st }}, 2018$.

How to cite this article: Lucchini-Raies C, Márquez-Doren F, Herrera-López LM, Valdés C, Rodríguez N. The lived experience of undergraduate student parents: roles compatibility challenge. Invest. Educ. Enferm. 2018; 36(2):e03. DOI: 10.17533/udea.iee.v36n2a03 
integrated role of father/mother-student. Conclusion. This study provides qualitative evidence that contributes to a comprehensive understanding of the experience of becoming a mother/father during the university studies; concluding that this life experience is presented as a process of role compatibility, which is necessary to support. For this, it is necessary to make visible the role of parents/students in university policies, with the aim of providing concrete support during this process of parallel transition in the lives of young people.

Descriptors: qualitative research; students; parents; life change events.

\section{La experiencia de estudiantes universitarios que son madres/padres: desafíos en la compatibilidad de roles}

Objetivo. Develar los significados atribuidos por estudiantes universitarios a su experiencia de convertirse en madre/padre durante sus estudios. Métodos. Se realizó un estudio fenomenológico en una universidad privada chilena. Dieciséis estudiantes de diferentes carreras de pregrado (ocho mujeres y ocho hombres) participaron en entrevistas en profundidad las cuales se grabaron. Se realizó un análisis fenomenológico de los datos que siguió el método de Streubert, cuidando el rigor de la investigación mediante el cumplimiento de los criterios establecidos por Guba y Lincoln durante el proceso de investigación. Resultados. El fenómeno de convertirse en madre/padre durante la etapa universitaria se develó a través de cuatro temas centrales: Emociones en conflicto; Movilización interna para abordar la situación; Posicionarse en un nuevo rol; y Necesidad de apoyo. La contribución central del estudio es la revelación del proceso de transformación hacia el rol integrado de padre/madre-alumno. Conclusión. Este estudio proporciona evidencia cualitativa que contribuye a una comprensión integral de la experiencia de convertirse en madre/padre durante la etapa universitaria. Como conclusión, esta experiencia de vida se presenta como un proceso de compatibilidad de roles, que es necesario apoyar. Para ello se requiere visibilizar el papel de los padres/madres estudiantes en 
las políticas universitarias con el objetivo de proporcionar un apoyo concreto durante este proceso de transición paralelo en la vida de los jóvenes.

Descriptores: investigación cualitativa; estudiantes; padres; acontecimientos que cambian la vida.

\section{A experiência vivida por estudantes universitários que são mães/pais: desafios na compatibilidade dos papéis}

Objetivo. Revelar os significados atribuídos por estudantes universitários à sua experiência de tornar-se em mãe/pai durante seus estudos. Métodos. Se realizou um estudo fenomenológico com estudantes numa Universidade particular chilena. Dezesseis estudantes de diferentes cursos de graduação (oito mulheres e oito homens) participaram em entrevistas em profundidade as quais foram gravadas. Se realizou uma análise fenomenológico dos dados que seguiu o método de Streubert, cautelando o rigor da investigação por meio do cumprimento dos critérios estabelecidos por Guba e Lincoln durante o processo de investigação. Resultados. 0 fenômeno de tornar-se em mãe/pai durante a etapa universitária se revelou através de quatro assuntos centrais: Emoções em conflito; Mobilização interna para abordar a situação; Posicionar-se num novo papel; e Necessidade de apoio. A contribuição central do estudo é a revelação do processo de transformação para o papel integrado de pai/mãe-aluno. Conclusão. Este estudo proporciona evidência qualitativa que contribui a uma compreensão integral da experiência de tornar-se em mãe/pai durante a etapa universitária; concluindo que esta experiência de vida se apresenta como um processo de compatibilidade de papéis, que é necessário apoiar. Para isto se requere visibilizar o papel dos pais/mães alunos nas políticas universitárias, com o objetivo de proporcionar um apoio concreto durante este processo de transição paralelo na vida dos jovens.

Descritores: pesquisa qualitativa; estudantes; país; acontecimentos que mudam a vida. 


\section{Introduction}

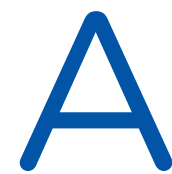

family is a human group integrated by various members and a social system where most human process occurs. The family environment has the capacity to provide the necessary physical, emotional, spiritual, and economic conditions for each member to reach their potential. The birth of a child in the early phase of family constitution is a very important period in the life of a couple as it signifies the incorporation of a new member to the family, who requires a large amounts of attention and care from their parents. This implies that both members of the couple must develop the roles of mother or father, respectively. ${ }^{(1)}$ Traditional family structures, for example parents and child/children living at the same home, are still the conventional type of family in Chile. ${ }^{(2,3)}$ However, there are several different types of family that must be considered, for example a mother or father living alone with their child/children, parents that do not live together, and grandparents raising their grandchildren. ${ }^{(2,3)}$ The process of becoming a mother or father is an experience marked by large internal demands, as well as external demands from the environment. Being a parent signifies adopting a new role and facing the challenge of successfully fulfilling this role. ${ }^{(4)}$

Higher education and university life demands considerable time and energy from the student, both from an academic and an emotional point of view. Students face a new world in which they must develop social abilities necessary to navigate this new environment, as well as develop and put into practice their intellectual abilities. ${ }^{(5)}$ When becoming a parent occurs at the same time as studying an undergraduate degree, students may experience a crisis that has the potential for a positive outcome if they face the challenge as an opportunity to grow and develop. In order to achieve a successful resolution of this crisis, students require additional support from their families, as well as from the higher education institution where they are studying. Institutional support is essential for the positive development of both the parental and student roles. ${ }^{(6)}$

Nurses and faculty members are called to share their knowledge and experience with undergraduate students in the process of becoming parents, and in this way support and guide them in the acquisition of their new parental role. The purpose of this support is to promote wellbeing and healthy development of the student and their family as they reconcile both roles of student and parent. ${ }^{(4)}$ Limited literature has been published exploring the phenomenon of the twin role of university student and parent in Chile, ${ }^{(7)}$ nevertheless, some international research on undergraduate/graduate parenthood analyses the way in which both roles are developed. These studies have shown that when there is lack of support, for example from family and/or from the higher education institution, student-parents perceive themselves as both poor students and poor parents. ${ }^{(5,8)}$ 
Given the lack of published research in this field, the aim of this current study was to explore the meaning students attributed to their experience of becoming a mother/father during their university life and its impact in family development.

\section{Methods}

Phenomenological Approach. Since this study intends to explore the lived experience of becoming a mother/father whilst studying an undergraduate degree, a phenomenological design was chosen. As faculty we are interested in comprehending students lived experience with regards to their lives, health, growth and development processes. ${ }^{(9)}$ Phenomenology as a research method is a rigorous, critical and systematic way to approach unknown phenomena. Its purpose is to comprehend the lived experience of certain phenomena, searching for meaning units of it. As part of the phenomenological research process the precise way in which the researchers interprets the meaning of the phenomenon under study is by immersing them self in the data and remaining open to the meaning the participants attribute to the phenomenon. The only way to really perceive the other's world is to remain as free as possible of preconceived ideas. After identifying the researchers' preconceived notions, they should be removed from consciousness. This is a process that requires the researchers to hold a neutral position with regards to their own beliefs and values in relation to the phenomenon. ${ }^{(9)}$

Participants and Ethical Considerations. The participants' inclusion criteria for this study were to be an undergraduate student attending a private Catholic university in Santiago, Chile that had experienced the transition to motherhood/ fatherhood during their university studies. Twentyeight undergraduate students were invited to participate in the study (12 women and 16 men) and 16 consented to participate (eight women and eight men). The selection of the participants was made through purposive sample in most cases, and the "snow ball" sampling method was used for the male participants. The nurse coordinator of the Healthy Campus Program at the University made initial contact with the students. The nurse called each potential participant and explained the aims, structure and ethical considerations of the study. If the student agreed to participate, she/he signed an informed consent form and was contacted by one of the three researchers that conducted the interviews. By a phone call or an e-mail, the researcher reiterated the aim of the study and scheduled the interview. Professors of the School of Nursing, with qualitative research experience, a campus nurse and an undergraduate nursing student, integrated the research team; the three female professors, all of them with master degree, conducted the interviews. The criteria used to determine the number of participants was the saturation of the data. The initial point of saturation was reached by to the sixth interview with female participants and the sixth interview with male participants, however, the interview process continued until saturation of the data was ensured. Ethical approval for the study was obtained through the Ethics Committee of the School of Nursing at Pontificia Universidad Católica de Chile. The average age of the participants was 25 years and all had become a parent during their undergraduate studies. The average age of their children was 3 years (range 6 months to 14 years). All but two of the participants lived in the capital city, Santiago, whilst the remaining two students came from other regions of the country. Regarding their academic situation, half of the participants had a curricular delay related with the maternity/paternity process. Nine of the participants lived with their parents, three with their partner, one with both parents and partner, two with their siblings, and one alone. Ten of the participants were studying and working at the same time, as a way of increasing their income to meet the needs of their child, and 14 received economic support from others (parents or their partner) to supplement their income.

Data Collection. The first three authors collected data through in-depth interviews from April to December 2013. During this process, the 
researchers recorded of their own feelings and emotions about the phenomenon under study through a process of journaling. The purpose of journaling was to separate the experiences described by the students from their own experiences. In-depth interviews were conducted in order to comprehend the individual experiences from the student's perspective and in this way, the researchers sought to understand these experiences through the spoken narration of the participants. In order to describe sociocultural characteristics of the sample, prior to interviewing participants completed a form denominated "Questionnaire for students" in order to gather demographic, academic, familial and socioeconomic information. One in-depth interview was conducted with each participant, with an open guiding question: Which has been your experience of becoming a mother/father during your undergraduate studies? Subsequent open questions were made to encourage further depth in the narrative when if necessary. The interviews were conducted by the professors and with the exclusive presence of the participants, in the faculty's offices. Interviews were audio taped and transcribed verbatim. The interviews lasted an average of 40 minutes. The audio recordings and transcriptions of the interviews were stored securely in a locked place and after the analysis process were deleted.

Data Analysis. Data was analyzed through a content analysis process, without using any software. ${ }^{(9)}$ The analysis of the first interview allowed for the identification of preliminary units of meanings. Thereafter, the rest of the interviews were analyzed until saturation of the data was achieved. The first analytical phase was completed as a group by the three researchers who conducted the interviews. During this phase, an initial analysis of the first three interviews was performed, the first units of meaning were extracted, and an analysis matrix was constructed. For the following interviews, each researcher performed an initial analysis separately, and in a second phase the three researchers conducted a joint analysis to identify clusters of meanings and central themes, using the phenomenological analytical process described by Streubert and Rinaldi. ${ }^{(9)}$ To confirm the results of the analysis, the structure of the phenomenon was sent back to three participants that validated these results.

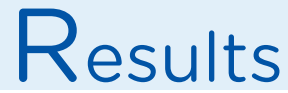

Four central themes of the phenomena of being a mother/father during undergraduate studies appeared: Conflicting emotions; Internal mobilization to address the situation; Positioning oneself in a new role; and Need for support. Each theme consisted of domains and subdomains. The experience of males and females was presented through the same four central themes, however, in some domains gender differences were found. A description of each theme is presented. The quotations that represent the experience of the participants were translated from Spanish into English:

Conflicting emotions. Students demonstrated that in a first stage of the process, they transited through a conflict of emotions, which involved assuming the new condition of father/mother at the same time as they continued being students. This caused an initial shock in their close environments: family and university: For me it was very difficult to accept my pregnancy, I had depression because I didn't accepted my son until I had him in my arms..., I regretted all the time, there were months during my pregnancy that I was in bed all the day, I did not want to do anything... (I14). Some participants described how their new status as a future mother/father triggered demonstrations of support, however in other cases, participants experienced discrimination by the university environment, especially in the case of females. This generated feelings of guilt because the students required support from others: There are people that include you in group work and there are people who say "I hate to work with this girl who has a baby'. However, the truth is that it did not affect so much that my classmates said that. Really what affected me were the opinions of the teachers (I8); I explained to them [teachers] that I had some trouble with my son and some 
of them told me well, nobody force you to have a baby... so then the perception of being a mother changes... and to be a college student and mom at the same time is seen as something terrible, like morally bad (I14).

Internal mobilization to address the situation. Once students had accepted their new life situation, they passed through a process of decision-making where they began to rethink the future. They needed to redirect their lives, which implied a change in priorities, and often, sacrificing activities that formed part of their daily lives. Male participants seemed to experience more intensely the loss of certain university activities and often described this process. Thus, both mothers and fathers described going through a process, not without obstacles and barriers, which allowed them to discover a new motivation to continue their studies. In this process, students were able to identify critical moments in the development of the dual role of student-parent: When my son was born I realized that maybe I could not continue with my studies... that I needed to look for other alternatives that allow me a work for a more stable future... and that was the way I found my vocation to become a teacher and I finished studying pedagogy (16); I always said that for being a mother and student you need a lot of strength and power because... you know... I have all the problems that the others students have... but sometimes I have my head elsewhere because, for example, my son is sick... (I6).

Positioning oneself in a new role. Once the child had born a change in the hierarchy of roles occurred, and the role of mother/father became the most important. Thus, participants were faced with the task of redistributing their priorities, trying to reconcile their maternal/paternal activities with their student activities. This involved making changes to their life project, with their son/daughter becoming the main motivation to move forward. While it is true that both mother and father go through a process of acquisition of maternal/paternal role, the female students seemed to perceive this change more acutely, since their biological condition forced them to miss their university activities during delivery and the immediate postpartum period: First of all, it is a responsibility because I am no longer in charge of myself, another person depends on me. It has been complicated to organize my time... There is no time left to be distracted... yes, and that was the complicated thing, that's why I suspended the first semester (19).

Need for support. Students reported that during this process they required constant and strong external support, identifying their families and the university environment as fundamental pillars of support. Those who received the required support indicated that a major aspect that had helped them to reconcile both roles was having support from home and from their teachers and peers at the university: Our parents were a pillar of support because they helped us take care of our daughter when we could not; they supported us financially while we were studying at the university. So they were an important support, without them we would have had to work and study and it would have been very difficult (I10). However, some participants indicated that they felt invisible to the authorities and lamented the lack of institutional policies that considered the condition of being a father/mother and student, which could be translated into concrete, practical support. In addition, students proposed some practical institutional support measures that would help students to assume the responsibilities of being a father/mother and student: The first support necessary is that the university recognizes the condition of being both father and student, which in itself is more difficult because of the multiple responsibilities... (19). In this way, the phenomenon is experienced as a process of simultaneous transition between the adoption of the maternal/paternal role and becoming a professional with a university degree. This process contains moments of high emotionality when students face the conflicting responsibilities of university and home life, and terminates with the adoption of a new integrated student-parent role. Coping with this new life situation requires internal mobilization of one's own resources and strong external support of the environment. This support becomes a fundamental pillar that 
facilitates or hinders the incorporation of this new role in their daily lives.

\section{Discussion}

The transformative process of becoming a mother requires an important mobilization of resources in the psychological, social and physical spheres. During this stage, females go through a period of enhanced vulnerability and face great challenges as they transit into motherhood. The process of becoming a mother has been described in four stages: (a) commitment, bonding and preparation for the arrival of the child during pregnancy; (b) getting to know the child and formation of attachment, learning to take care of the child and physical recovery during the first weeks postpartum; (c) moving towards a new normalcy during first four months postpartum; and (d) attainment of a maternal identity at around four months postpartum. These stages overlap each other and are affected by maternal, child, family and environmental variables, which in turn influence the duration of each stage. ${ }^{(4)}$ In the case of males, the process of becoming a father also provokes various emotions and signifies a radical change in their lives. During this process they are exposed to new situations and learn new skills in response to the challenges imposed by their new role as a father, and as they transition into fatherhood, they consolidate this new role. ${ }^{(10-15)}$

The transformative process of becoming a mother or father may differ in the case of individuals whom experience this transformation during their university studies, since a significant proportion of these individuals are still in the final stages of adolescence. ${ }^{(7,16,17)}$ Pregnancy during adolescence generates new emotions, new actions as well as imbalances for individuals who are still experiencing the vulnerabilities inherent to this developmental stage. ${ }^{(16)}$ These young people experience two significant transitions simultaneously: one towards adulthood and another towards parenthood, therefore, they face a combined stress related to raising their child and achieving independence as an adult. Consequently, young parents generally have fewer resources to facilitate their process of transition to parenthood..$^{(7,17)}$

When the process of becoming a mother or father coincides with an individual's university studies, additional difficulties may present themselves in relation to the physical and emotional exhaustion of assuming these responsibilities, considering that the requirements each role, student and parent, may enter into conflict. This generates a dilemma for the individual as they may feel incapable of fulfilling either their parental or student role, or even worse, feel incompetent in both roles. $(8,16,18)$

In accordance with results from this current study, previous studies have shown that the process of becoming a student-parent is characterized by the presence of contradictory emotions, the need to both mobilize internal resources to face the situation and to identify oneself in the new role. $(7,8,16,19,20)$

A fundamental aspect of this process, highlighted by the participants of this study, is the perceived support of family and the university institution. In particular, family is regarded as the central pillar of support for the individual assuming their new role of student-parent, since family members frequently provide emotional and financial support, and may also care for the child when the student is unable to do so due to the demands of their university studies. ${ }^{(18,20-22)}$

Concerning institutional support, participants in this current study described a diversity of experiences, some students perceived that university supported them, others shared negative experiences, and whilst others described feeling that, their situation was made invisible in the university setting. This final point is consistent with previous studies that describe a self-imposed invisibility by mothering students adapting to institutional policies and norms that do not take into consideration the possibility that students may be fulfilling their maternal role during this stage of life. ${ }^{(20,23)}$ The lack of institutional consideration for parenting students may generate difficulties on one hand, in relation to the student's 
ability to fulfil their maternal/paternal role, in the construction of the previously mentioned selfconcept as a parent, and even influencing the parent-child attachment style; and on the other hand, in their self-perception as a student, which influences their academic performance. . $^{(8,20,24)}$

When university policies recognize the unique situation of students being parents and grant them the necessary support to fulfil their dual role, the university environment has the potential to become a setting for enriching experiences that not only promote the integral development of the student, but also positively influence the development of their child and their new family ${ }^{(20)}$ and contribute to a more inclusive university environment. ${ }^{(8,23)}$ Various university institutions have developed specific policies designed to protect and support mothering students, however fewer initiatives exist taking into account that needs of fathering students. . $^{(5,25-27)}$

The phenomenon of becoming a mother or father during the university years was multidimensional in nature, and revealed through four central themes. These themes take into account the emotional process in which various, positive and negative feelings, come into conflict, as the individual faces the challenges of university studies and parenthood. In order to fulfil the responsibilities of both roles, the student needs to mobilize different resources, a process that leads to a transformation towards a new integrated role of parent-student. In order for this transformation to be a process rich in positive experiences, the student-parent requires diverse sources of support, in particular the support of family and friends, in addition to support provided by the university institution. In search of a comprehensive understanding of the phenomenon under study, the central contribution of the study is the revelation of the lived experience of student-parents, in particular their process of transformation towards the integrated role of father/mother-student.

All faculty members should be aware of students that are facing their motherhood/fatherhood, specially nursing faculty who has the responsibility to provide a nourish environment for the student and the child, in terms of promoting a healthy life, for parents and children

Finally, there is a need to make the role of student-parent visible in university policies, with the objective of providing concrete support during this unparalleled process of transition in the life of the young person. Several recommendations for providing concrete support include flexible study timetables, implementation of policies that promote breastfeeding within the institution, provision of childcare options whilst parents are in classes, and ensuring academic mentors are aware of the unique situation of these students.

In regards to the limitations of this study, the results of this research reflect the reality of student parents in only one university. Furthermore, this research considers only the perspective of the student parents, not those of teachers and university authorities. Further research to address these limitations is recommended. 


\section{References}

1. Garrido MC, Marchán M. Adopción del rol materno en madres adolescentes primerizas según grupo de convivencia. Rev. Psicol. Trujillo. 2011; 13(1):11-28.

2. Cerda J. La familia chilena en el Bicentenario. Trilogía Cienc. Tecnol. Soc . 2010; 22(32):71-8.

3. Márquez F, Bertolozzi MR. Rol Social y Participación del Padre en la Crianza de sus hijos/as en la Historia de Chile. Horiz. Enferm. 2013; 24(1):42-9.

4. Alvarado L, Guarin L, Cañon-Montañez W. Adopción del rol maternal de la teorista Ramona Mercer al cuidado de enfermería binomio madre - hijo: reporte de caso en la unidad materno infantil. Rev. Cuid. 2011; 2(1):195-201.

5. Springer KW, Parker BK, Leviten-Reid C. Making space for graduate student parents: Practice and politics. J. Fam. Issues. 2009; 30(4):435-57.

6. Morales E, Solanelles AM, Mora SR, Miranda O. Embarazo no deseado en alumnas universitarias. Rev. Cub. Med. Mil. 2013; 42(2):153-63.

7. Molina R. El padre adolescente, su relación parental y de pareja. Última Décad. 2011;19(35):89-110.

8. Estes D. Managing the Student-Parent Dilemma : Mothers and Fathers in Higher Education. Symb. Interact. 2011; 34(2):198-219.

9. Streubert HJ, Rinaldi D. Qualitative Research in Nursing. Advancing the Humanistic Imperative. Fifth Ed. Philadelphia: Lippincott Williams \& Wilkins; 2011.

10. Ball J. Indigenous fathers' involvement in reconstituting "circles of care." Am. J. Community Psychol. 2010; 45(1-2):124-38.

11. Dallos R, Nokes L. Distress, loss, and adjustment following the birth of a baby: A qualitative exploration of one new father's experiences. J. Constr. Psychol. 2011; 24(2):144-67.

12. Lemay CA, Cashman SB, Elfenbein DS, Felice ME. A qualitative study of the meaning of fatherhood among young urban fathers. Public Health Nurs. 2010; 27(3):221-31.

13. Robbers MLP. Facilitating fatherhood: A longitudinal examination of father involvement among young minority fathers. Child. Adolesc. Soc. Work J. 2009; 26(2):121-34.

14. Chin R, Hall P, Daiches A. Fathers' experiences of their transition to fatherhood: A metasynthesis. J. Reprod. Infant. Psychol. 2011; 29(1):4-18.

15. Suárez-Delucchi N, Herrera P. La Relación del Hombre con su Primer (a) Hijo (a) Durante los Primeros Seis Meses de Vida : Experiencia Vincular del Padre. Psykhe. 2010; 19(2):91-104.

16. Estupiñán-Aponte MR, Rodríguez-Barreto L. Aspectos psicosociales en universitarias embarazadas. Rev. Salud Pública. 2009; 11(6):988-98.

17. Gilmer C, Buchan JL, Letourneau N, Bennett CT, Shanker SG, Fenwick A, et al. Parent education interventions designed to support the transition to parenthood: A realist review. Int. J. Nurs. Stud. 2016; 59:118-33.

18. Reddick RJ, Rochlen AB, Grasso JR, Reilly ED, Spikes DD. Academic fathers pursuing tenure: A qualitative study of work-family conflict, coping strategies, and departmental culture. Psychol. Men Masculinity. 2012; 13(1):1-15.

19. Figueroa CA, Cantor CJS, Guerrero AHP, Romero CMC. Meaning of parenting as a teenager. Investig. Educ. Enferm. 2017; 35(3):348-55.

20. D’Avirro MJ. Madres e hijos dos etapas evolutivas beneficiadas por la inclusión universitaria. Int. J. Dev. Educ. Psychol. 2017; 1(1):257-68.

21. Lou Z, Zeng G, Orme JG, Huang L, Liu F, Pang X, et al. Breastfeeding knowledge, attitudes, and intention in a sample of undergraduate students in Mainland China. J. Hum. Lact. 2014; 30(3):331-9.

22. Dinour LM, Beharie N. Lessons learned from a student-led breastfeeding support initiative at a US urban public university. J. Hum. Lact. 2015; 31(3):341-3.

23. Mwangi-chemnjor C. Single student parents on the margins. Int J Contemp Appl Sci. 2016;3(3):193-206.

24. Low Concha A. Caractarísticas Sociodemográficas Asociadas al Tipo de Apego en Madres y Padres, Estudiantes Universitarios, de la Región de Valparaíso. Rev Psicol Univ Viña del Mar. 2012;2(3):97-123. 
25. Taylor JS, MacNamara M, Groskin A, Petras LI. Medical Student-Mothers. R. I. Med. J. 2013; (March):42-5.

26. Pugh E. Student pregnancy and maternity : implications for higher education institutions [Internet]. United Kingdom: Equality Challenge Unit; 2010 [cited 24 Apr 2017]. Available from: http://www.ecu.ac.uk/publications/ files/student-pregnancy-and-maternity-implications-for-heis.doc/view

27. Facultad de Medicina UC. Reglamento del Estudiante de Pregrado Madre y Padre de las Carreras de la Facultad de Medicina [Internet]. Santiago: Pontificia Universidad Católica de Chile; 2016 [cited 24 Apr 2017]. Available from: http://enfermeria.uc.cl/images/stories/pregrado/reglamento_para_estudiantes_madres_padres_fac_juridica.pdf 